\title{
Pneumocystis jirovecii pneumonija u imunokompromitiranog pacijenta neinficiranog virusom humane imunodeficijencije: prikaz slučaja
}

\section{Pneumocystis jirovecii pneumonia in non human immunodeficiency virus infected immunocompromised patient - case report}

\author{
Klara Pospiš ${ }^{1^{*}}$, Ivica Pavić
}

${ }^{1}$ Medicinski fakultet, Sveučilište u Rijeci, Rijeka

${ }^{2}$ Katedra za zarazne bolesti, Medicinski fakultet, Sveučilište u Rijeci, Rijeka

*Dopisni autor:

Klara Pospiš

Medicinski fakultet, Sveučilište u Rijeci Braće Branchetta 20, 51000 Rijeka e-mail: klara.pospis@gmail.com
Sažetak. Cilj: Analizirati dijagnostičke postupke kod sumnje na pneumoniju u imunokompromitiranih pacijenata s naglaskom na molekularnu dijagnostiku koja omogućuje brzo identificiranje uzročnika i sukladno tome primjenu učinkovite kauzalne terapije. Prikaz slučaja: Pacijentica stara 64 godine primljena je u Kliniku za infektivne bolesti zbog febriliteta do $39{ }^{\circ} \mathrm{C}$ u trajanju od devet dana te blagog kašlja. Laboratorijski parametri ukazivali su na akutnu infekciju. Radiogram pluća pokazao je patološki intersticijski crtež bilateralno. Dosada je pacijenticu kontrolirao hematolog, s obzirom na to da je podvrgnuta alogenoj transplantaciji hematopoetskih matičnih stanica zbog akutne mijeloične leukemije. Postavila se sumnja na pneumoniju. Promptno su ordinirane hemokulture i urinokultura te je uzorak sputuma poslan na analizu. Budući da su kulture bile sterilne, a sputum bakteriološki i mikološki negativan, pacijentica je bila upućena na bronhoskopiju s bronhoalveolarnom lavažom (BAL). Mikrobiološka i citološka analiza ispirka nije bila specifična za postavljanje etiološke dijagnoze, stoga je uzorak obrađen testovima lančane reakcije polimerazom (engl. polymerase chain reaction; $\mathrm{PCR}$ ) na prisutnost najčešćih respiratornih patogena, kao i na Mycobacterium tuberculosis i Pneumocystis jirovecii. U međuvremenu je učinjena kompjutorizirana tomografija visoke rezolucije (engl. high resolution computerized tomography, HRCT) toraksa koja je potvrdila obrazac atipične pneumonije obostrano. Po dobivanju pozitivnog nalaza PCR-a na Pneumocystis jirovecii iz bronhoalveolarnog lavata pacijentica se liječila trimetoprim-sulfometoksazolom i prednisonom te je otpuštena dobrog općeg stanja. Zaključak: Budući da je bolest brzo dijagnosticirana te je i odgovarajuće liječenje na vrijeme započeto, pacijentica je ozdravila od Pneumocystis jirovecii pneumonije (PJP), koja ima prosječnu smrtnost od $30-50 \%$.

\section{Ključne riječi: HRCT; kemoprofilaksa; Pneumocystis jirovecii; Pneumocystis jiroveci}

Abstract: Aim: The aim of this paper is to analyse the procedure of diagnosing pneumonias in immunocompromised patients and to point out the importance of molecular diagnostic tests that enable the identification of pathogens causing the disease and administering adequate causal therapy accordingly. Case report: We report a case of a 64-years-old female patient presented with temperature up to $39{ }^{\circ} \mathrm{C}$ and mild cough for nine days. Patient was hospitalized in a clinic for infectious diseases. So far, the patient was controlled by hematologists due to allogenic transplantation of hematopoietic stem cells preformed because of acute myelogenous leukemia. In further diagnostic, laboratory parameters indicated acute infection and the radiogram of the lung showed pathological interstitial drawing bilaterally. Pneumonia was suspected as a most likely cause. Promptly ordered hemocultures and urinecultures were sterile, and the sputum was bacteriological and mycological negative, the patient was referred to bronchoalveolar lavage bronchoscopy. The microbiological and cytological analysis of the lavage was not specific to the etiologic

http://hrcak.srce.hr/medicina 
diagnosis, therefore the sample was treated with polymerase chain reaction (PCR) tests for the presence of the most common respiratory pathogens, as well as on Mycobacteriumtuberculosis and Pneumocystis jirovecii. Meanwhile, a computerized high resolution tomography (HRCT) was performed, which confirmed the atypical pneumonia pattern bilaterally. After obtaining a positive PCR finding on Pneumocystis jirovecii from the bronchialveolar lavage, the patient was treated with trimethoprimsulfomethoxazole and prednisone. Therapy was successful and patient was released in a good general condition. Conclusion: Pneumocystis jirovecii pneumonia has an average mortality of $30-50 \%$. The patient was recovered, since the disease was diagnosed and appropriate treatment was initiated on time.

Key words: HRCT; chemoprophylaxis; Pneumocystis jirovecii; Pneumocystis jiroveci

\section{UVOD}

Gljiva Pneumocistys jirovecii je prototip oportunističkog patogena koji izaziva životno ugrožavajuće pneumonije u imunokompromitiranih pacijenata. Poznato je da $50 \%$ odrasle populacije s očuvanim kompetencijama imunosnog sustava ima asimptomatsku kolonizaciju pluća ovim uzročnikom te predstavlja važan rezervoar za širenje mikroorganizama na imunokompromitirane pacijente ${ }^{1}$. lako je dokazana učinkovitost kemoprofilakse rizičnih skupina trimetoprimom i sulfometoksazolom, jasne smjernicu za njenu primjenu postoje isključivo za osobe inficirane virusom humane imunodeficijencije (HIV, engl. human immunodeficiency virus $)^{2}$. Prenosi se kapljičnim putem. Infekcija gotovo isključivo zahvaća pluća. Febrilitet, tahipneja, progresivna dispneja i neproduktivni kašalj sastavni su dio kliničke slike ${ }^{3}$. Nastup, težina i ishod pneumonije varira ovisno o uzroku imunosupresije. Nužna je što brža analiza respiratornog materijala. S obzirom ne to da Pneumocystis jiroveci ne raste na konvencionalnim mikrobiološkim podlogama, uobičajeno se dijagnosticira mikroskopskim promatranjem obojenog preparata. Ponekad to nije dovoljno za postavljanje konačne dijagnoze, već se do nje dolazi kombinacijom odabranih radioloških i molekularnih metoda, što je i učinjeno u slučaju opisane pacijentice. Ciljanom molekularnom dijagnostikom postigla se brza identifikacija uzročnika, čime se skratilo trajanje široke empirijske terapije. Glavni cilj ovog prikaza slučaja je osvijestiti o važnosti što bržeg uvođenja ciljane, kauzalne terapije, čime se smanjuje rizik nastanka rezistencije na antimikrobne lijekove.

\section{PRIKAZ SLUČAJA}

Pacijentica stara 64 godine primljena je u Kliniku za infektivne bolesti zbog febriliteta do $39{ }^{\circ} \mathrm{C} \mathrm{u}$ trajanju od devet dana te blagog kašlja. U fizikalnom statusu kod prijema uočen je pooštren šum disanja obostrano nad cijelim plućima.

Klinička prezentacija PJP-a uvelike ovisi o tome radi li se o HIV-pozitivnim ili HIV-negativnim pacijentima. Postoje jasno definirane smjernice za kemoprofilaksu PJP-a u HIV-pozitivnih, međutim, za HIV-negativne osobe koje su imunokompromitirane i potencijalno predisponirane PJP-om ne postoje tako jasno definirane smjernice, stoga je uloga kemoprofilakse PJP-a u HIV-negativnih pacijenata i dalje kontroverzna.

Laboratorijski je utvrđena upadljiva razina C-reaktivnog proteina od 196,8 mg/L i leukocita od 13,8 x $10^{9} / \mathrm{L}$. Na inicijalnom radiogramu grudnih organa prikazan je patološki intersticijski crtež obostrano hilobazalno, nepravilni infiltrati plućnog parenhima u lijevom gornjem te $u$ desnom srednjem i donjem plućnom polju. Anamnestički je doznato da je pacijentica bila podvrgnuta alogenoj transplantaciji hematopoetskih matičnih stanica zbog akutne mijeloične leukemije unatrag 18 mjeseci te se redovito kontrolirala kod hematologa. S obzirom na kompromitirani imunološki sustav uslijed hematološkog oboljenja, spomenutih laboratorijskih abnormalnosti i patološki nalaz radiograma pluća, postavljena je sumnja na pneumoniju. Započeto je empirijsko antimikrobno liječenje parenteralnim oblicima koamoksiklava, levofloksacina i flukonazola. S ciljem što bržeg postavljanja konačne dijagnoze, pronalaska uzročnika i uvođenja ciljane terapije ordinirane su hemokulture, urinokultura i pregled sputuma. Budući da su kulture bile sterilne, a sputum bakteriološki i mikološki negativan, indiciran je pregled pulmologa koji je učinio bronhoskopiju s bronhoalveolarnom lavažom (BAL). Mikrobiološka i citološka analiza ispirka nije bila specifična za postavljanje etiološke dijagnoze, sto- 
ga je uzorak obrađen testovima lančane reakcije polimerazom (engl. polymerase chain reaction; $P C R$, ) na prisutnost najčešćih respiratornih patogena, kao i na Mycobacterium tuberculosis i Pneumocystis jirovecii. Nadalje, kako se inicijalna terapija nije pokazala učinkovitom, liječenje je nastavljeno meropenemom, kotrimoksazolom i vorikonazolom. Također, pacijentica je bila tretirana i simptomatski (tromboprofilaksa, gastroprofilaksa, profilaksa Herpes Simplex virus infekcije aciklovirom, oksigenoterapija na nosni kateter i adekvatna

Brza identifikacija uzročnika pomoću dostupnih metoda molekularne dijagnostike u svrhu provedbe kauzalne terapije važna je jer pridonosi smanjenju prevalencije rezistencije na antibiotike uzrokovane prolongiranom primjenom široke empirijske terapije.

hidracija). Zbog pogoršanja općeg stanja u vidu progresivne dispneje i razvoja parcijalne respiracijske insuficijencije pacijentica je upućena na kompjutoriziranu tomografiju visoke rezolucije (engl. high resolution computerized tomography; HRCT) toraksa po standardnom protokolu. Pretragom su tada utvrđene različito velike zone alveolarne konsolidacije plućnog parenhima bilateralno, pojedine okružene ground-glass arealima, što govori u prilog žarištima atipične pneumonije. Po dobivanju pozitivnog nalaza PCR-a na Pneumocystis jirovecii iz bronhoalveolarnog lavata, a uz negativne nalaze ostalih uzročnika iz respiratornog panela, liječenje je nastavljeno kotrimoksazolom i prednisonom uz postepenu redukciju doze. Kao nuspojava liječenja kotromoksazolom zabilježena je hiperkalemija koja je regulirana otopinama glukoze uz brzodjelujući inzulin, diuretik i ionski izmjenjivač. Na provedenu terapiju došlo je do zadovoljavajućeg kliničkog i laboratorijskog oporavka. Kontrolni radiogram grudnih organa pokazao je gotovo potpunu regresiju upalnog infiltrata desno, ali stanovitu progresiju upale ljevostrano, što se istumačilo dijelom imunorekonstruktivnog sindroma. Naposljetku je pacijentica otpuštena dobrog općeg stanja uz preporuku nastavka liječenja trimetoprim-sulfometoksazolom i prednisonom te kontrolama infektologa po dogovoru.

\section{RASPRAVA}

Gljivična infekcija pluća poznata pod nazivom pneumocistoza uzrokovana je oportunističkim patogenom, gljivom Pneumocystis jirovecii (ili jiroveci). Uzročnik je do 1976 . godine bio poznat pod imenom Pneumocystis carinii. Pneumonija uzrokovana s Pneumocystis jirovecii (PJP) jedna je od najčešćih oportunističkih infekcija u pacijenata sa sindromom stečene imunodeficijencije ${ }^{4}$. Zbog toga u literaturi postoje jasno definirane smjernice za kemoprofilaksu PJP-a u navedenih pacijenata ${ }^{2}$. U pacijenata koji nisu inficirani virusom humane imunodeficijencije, a imunosuprimirani su iz drugih razloga, prognoza PJP-a je znatno lošija, s mortalitetom od $30-50 \%{ }^{5}$. Uzrok tome je najvjerojatnije zakašnjelo postavljanje dijagnoze i samim time odgađanje neophodne terapije ${ }^{3}$. Također, korist kemoprofilakse u HIV-pozitivnih pacijenata je neupitna, međutim za HIV-negativne osobe koje su imunokompromitirane i potencijalno predisponirane PJP-om ne postoje tako jasno definirane smjernice, već samo preporuke za kliničare potkrijepljene istraživanjima ove problematike, stoga je uloga kemoprofilakse PJP-a u HIV-negativnih pacijenata i dalje kontroverzna ${ }^{6}$.

Klinička prezentacija PJP-a uvelike ovisi o tome radi li se o HIV-pozitivnim ili HIV-negativnim pacijentima. Tipično je da je u pacijenata zaraženih HIV-om klinički tijek podmukao i dugotrajan. Prisutna je povišena temperatura, dispneja pri manjem naporu i suhi kašalj koji traje tjednima, katkad i mjesecima ${ }^{3}$. $\mathrm{S}$ druge strane, u pacijenata $s$ drugim tipovima imunosupresije PJP se uglavnom manifestira brzim razvojem respiratorne insuficijencije, febrilitetom, neproduktivnim kašljem, tahipnejom i teškom dispnejom ${ }^{3-4}$. Opisana simptomatologija bila je prisutna u naše pacijentice tijekom boravka u Klinici za infektivne bolesti. U samom prikazu slučaja opisan je dijagnostičkoterapijski postupak kod sumnje na pneumoniju u pacijentice imunosuprimirane zbog hematološkog oboljenja.

Tijekom posljednja tri desetljeća dijagnostika PJPa napredovala je k manje invazivnim metodama. Nekad se za potvrdu dijagnoze izvodila otvorena biopsija pluća7. Danas se uglavnom rabi PCR, čija 
je osjetljivost veća od $85 \%$ i specifičnost veća od $90 \%^{3}$. Za razlikovanje kolonizacije od infekcije od koristi je PCR u realnom vremenu, iako ciljani geni i referentne vrijednosti još uvijek nisu u potpunosti utvrđeni ${ }^{8}$. Inducirani iskašljaj je najprikladniji uzorak za analizu, s obzirom na to da se dobiva najmanje invazivnim putem, a osjetljivost mu se kreće između 50 - $90 \%$. Ako iskašljaj nije moguće dobiti, indicirana je bronhoskopija $s$ BAL-om, a osjetljivost je tada veća od $90 \%{ }^{3}$.

Od radioloških dijagnostičkih alata, osim konvencionalnog radiograma pluća, koristi se i HRCT. Smatra se zlatnim standardom u procjeni bolesti plućnog intersticija te je koristan u postavljanju konačne dijagnoze i usmjeravanju biopsije, ako je ona potrebna ${ }^{9}$. Također, prisutnost ground glass areala na HRCT-u nije specifična za PJP, međutim, njihova odsutnost snažno sugerira da nije riječ o PJP-u ${ }^{5}$. Osim opisanih, kao pomoćna metoda u detektiranju PJP-a može poslužiti i određivanje betaD-glukana u serumu, s obzirom na to da je to sastojak gljivične stijenke ${ }^{8}$. Budući da je bolest brzo dijagnosticirana zahvaljujući molekularnoj dijagnostici (PCR) te je i odgovarajuće liječenje na vrijeme započeto, pacijentica je ozdravila od PJP-a.

\section{ZAKLJUČAK}

Prikazani slučaj potvrđuje da je pravodobnom sumnjom kliničara na pneumoniju uzrokovanu $\mathrm{s}$ Pneumocystis jirovecii te uz pomoć metoda molekularne dijagnostike moguće pravovremeno dijagnosticirati i izliječiti pacijenta od opisane životno ugrožavajuće bolesti. Stoga je edukacija o brzoj identifikaciji uzročnika pomoću dostupnih metoda molekularne dijagnostike u svrhu provedbe kauzalne terapije važna, jer pridonosi smanjenju prevalencije rezistencije na antibiotike uzrokovane prolongiranom primjenom široke empirijske terapije. S obzirom na to da je pojava rezistencije na antibiotike globalni javnozdravstveni problem 21. stoljeća, podizanje svijesti o toj problematici zasigurno je vrlo značajno.

Izjava o sukobu interesa: Autori izjavljuju da ne postoji sukob interesa.

\section{LITERATURA}

1. Gigliotti F, Wright TW. Pneumocystis: Where Does It Live?. PLoS Pathog [Internet]. 2012;8. [cited 2019 Apr 28]. Available from: https://doi.org/10.1371/journal.ppat.1003025.

2. AIDS info [Internet]. Guidelines for the prevention and treatment of opportunistic infections in HIV-infected adults and adolescents: recommendations from the Centers for Disease Control and Prevention, the National Institutes of Health, and the HIV Medicine Association of the Infectious Diseases Society of America. [cited 2019 Apr 28]. Available from: http://aidsinfo.nih.gov/contentfiles/Ivguidelines/adult_oi.pdf.

3. Pavliša G, Hećimović A, Džubur F, Samaržija M. Pneumonije $u$ imunosuprimiranih bolesnika. Medicus 2016;25:65-71.

4. Huang L, Cattamanchi A, Davis JL, Den Boon S, Kovacs J, Meshnick $S$ et al. HIV-Associated Pneumocystis Pneumonia. Proc Am Thorac Soc 2011;8:294.

5. Begovac J, Božinović $D$, Lisić M, Baršić B, Schönwald S. Infektologija. Prvo izdanje. Zagreb: Profil, 2006;675-7.

6. Liebling M, Rubio E, le S. Prophylaxis for Pneumocystis jiroveci pneumonia: is it a necessity in pulmonary patients on high-dose, chronic corticosteroid therapy without AIDS? Expert Rev Respir Med 2015;9:171-81.

7. Kroe DM, Kirsch CM, Jensen WA. Diagnostic strategies for Pneumocystis carinii pneumonia. Semin Respir Infect 1997; 12:70-8.

8. Song $Y$, Ren $Y$, Wang $X$, Li R. Recent Advances in the Diagnosis of Pneumocystis pneumonia. Med Mycol J 2016;57:111-6.

9. Vučetić Zekan M, Marušić A, Mažuranić I, Neralić-Meniga I, Peroš Golubičić T, Sertić Milić H. HRCT u procjeni plućnih manifestacija u bolestima vezivnog tkiva. 5 . kongres hrvatskih pulmologa s međunarodnim sudjelovanjem; 2010 Oct 7-10; Dubrovnik, Hrvatska. 2010;19. 